\title{
In memoriam Štefici Bahtijarević (1936. - 2018.)
}

U prosincu prošle godine, nakon duge bolesti, napustila nas je naša draga kolegica, suradnica i prijateljica Štefica Bahtijarević, čija je karijera obilježila razvoj Instituta za društvena istraživanja u Zagrebu.

Štefica Bahtijarević rođena je 25. 11. 1936. godine u mjestu Žabljak pored Bjelovara. Osnovnu školu završila je u Rovišću, gimnaziju u Bjelovaru, a na Filozofskom fakultetu Sveučilišta u Zagrebu diplomirala je psihologiju. Prvo radno mjesto bila joj je tvornica „Dalmatinka“ u Sinju, gdje je radila kao industrijska psihologinja. Istovremeno je počela raditi i kao terenska suradnica na istraživačkim projektima Instituta za društvena istraživanja Sveučilišta u Zagrebu (IDIS).

U Institutu se zaposlila 1967. godine kao asistentica u Odjelu za proučavanje ateizma i religije. Od početka karijere sudjelovala je u organiziranju i provođenju terenskih istraživanja iz područja sociologije religije. $\mathrm{Na}$ temelju rezultata istraživanja objavljivala je brojne studije i članke. Doktorirala je 1974. godine na Odsjeku za psihologiju Filozofskog fakulteta Sveučilišta u Zagrebu s disertacijom „Religijsko pripadanje u uvjetima sekularizacije društva“. Iste godine postala je i znanstvena suradnica u Institutu. Godine 1978. postala je voditeljica radne grupe za proučavanje ateizma i religije.

Uz znanstveno-istraživački rad, Štefica je paralelno sudjelovala i u sveučilišnoj nastavi na nekoliko fakulteta, a često je držala predavanja i seminare u svrhu obrazovanja nastavnika i odgajatelja.

Bila je i društveno-politički angažirana. Tijekom osamdesetih godina isticala se radom u Socijalističkom savezu radnog naroda Hrvatske te je u dvama mandatima bila i delegatkinja Saveznog vijeća Skupštine SFR Jugoslavije, gdje se posebno angažirala na izradi Rezolucije o daljnjem razvoju znanstvenoistraživačke djelatnosti u SFRJ.

Direktoricom Instituta postala je 1987. godine. U mirovinu je otišla 1996. godine kao znanstvena savjetnica u trajnom zvanju.

Tijekom svoje znanstveno-istraživačke karijere Štefica Bahtijarević vodila je brojne znanstveno-istraživačke projekte, većinom u području sociologije religije. Objavila je na desetine znanstvenih i stručnih radova prvenstveno u području sociologije religije, ali i u područjima istraživanja javnog mnijenja i socijalne psihologije. 
Zalagala se, i osobno je u skladu s tim djelovala, za uključivanje žena u sve sfere života, od znanosti do politike. Pomicala je mnoge granice, već i izborom religije kao područja svog znanstvenoistraživačkog rada u vremenu kada to nije bilo baš društveno poželjno. Širila je obzore u tom području i kroz svoj znanstveni rad i kroz društveni i politički angažman. U projekte i poslijediplomski studij uključivala je ondašnje znanstvenike disidente koji nigdje nisu mogli dobiti posao te intelektualce iz različitih znanstvenih područja, uključujući čuvene teologe iz razdoblja sedamdesetih i osamdesetih.

U Institutu za društvena istraživanja, u kojemu je provela gotovo čitav radni vijek - od znanstvene asistentice do znanstvene savjetnice, razdoblje u kojem je Štefica bila direktorica pamtimo kao zlatno doba Instituta, obilježeno velikim zajedničkim projektima, razvojem različitih znanstvenih područja te duhom prijateljstva i nadasve solidarnosti.

Kao njene dugogodišnje kolegice i suradnice, godinama smo bile dijelom jednog iznimnog, sadržajnog, dinamičnog života u kojem je bilo puno strasti za znanstvenoistraživački rad, ali i puno radosti, ljubavi i veselja. Razmišljajući o povijesti institutskih, a i naših osobnih odnosa sa Šteficom, i razgovarajući s prijateljima i kolegama zaključujemo: naviru samo sjećanja puna smijeha i dragosti.

Nedostajat će nam Štefica, njeno prijateljstvo, njen optimizam i smisao za humor.

Ankica Marinović Dinka Marinović Jerolimov 